\title{
Pleasant parosmia with regard to own stool after SARS-CoV-2 infection
}

\author{
José Halabe-Cherem*, Jorge C. Salado-Burbano and Haiko Nellen-Hummel
}

Internal Medicine Department, The American British Cowdray Medical Center, Mexico City, Mexico

\begin{abstract}
Coronavirus disease 2019 (COVID-19) has had a significant global impact due to the millions of deaths it has caused secondary to respiratory failure. However, the disease has also been associated with a wide array of manifestations in other organ systems. Among them, the presence of anosmia, which occurs in up to half the patients, has become a new sign of alarm to suspect the infection. Although up to $90 \%$ of affected patients will experience an improvement of their olfactory alterations within a month after the infection, the variety and severity of olfactory disturbances clearly cannot be summarized by the dichotomy of having anosmia or not. Parosmias are a type of olfactory dysfunction characterized by altered perception of odors, which can reflect both damage at some level of the olfactory tract, as well as the possibility of reversibility of said damage. The present manuscript describes possible olfactory disturbances associated with COVID-19, their pathophysiology, and potential clinical significance.
\end{abstract}

KEY WORDS: COVID-19. Olfactory disorders. Parosmia. Stool.

\section{Parosmia agradable a materia fecal propia posterior a la infección por SARS-CoV-2}

\section{Resumen}

La enfermedad por coronavirus 2019 (COVID-19) ha tenido un impacto mundial trascendente por los millones de muertes que ha causado secundarias a insuficiencia respiratoria. Sin embargo, la enfermedad también se ha asociado a una amplia gama de manifestaciones en otros sistemas. Entre ellas, la presencia de anosmia, la cual ocurre en hasta mitad de los pacientes, se ha vuelto un nuevo dato de alarma para sospechar la infección. Aunque hasta el 90\% de los pacientes afectados presentarán mejoría de sus alteraciones olfatorias dentro del mes posterior a su cuadro, la variedad y gravedad de alteraciones olfatorias claramente no pueden resumirse en la dicotomía de tener o no anosmia. Las parosmias son un tipo de alteración olfatoria caracterizadas por percepciones alteradas de los olores, las cuales pueden reflejar tanto daño a algún nivel del tracto olfatorio, así como la posibilidad de reversibilidad de dicho daño. En el presente manuscrito se describen las posibles alteraciones olfatorias asociadas a COVID-19, su fisiopatología, y potencial significancia clínica.

PALABRAS CLAVE: COVID-19. Trastornos olfatorios. Parosmia. Materia fecal.

More than one year has elapsed since the first cases of coronavirus disease 2019 (COVID-19) were reported in Wuhan, China, in December 2019. Ever since, a pandemic has swept over the world, affected billions of people, and caused the death of millions.
Although the high impact of the disease has been mainly attributed to its pulmonary manifestations, it has become evident that COVID-19 is a potentially multi-systemic disease, capable of causing musculoskeletal, pulmonary, cardiovascular, gastrointestinal,
Correspondence:

*José Halabe-Cherem

E-mail: jhalabe@ hotmail.com
Gac Med Mex. 2021;157:636-638

Contents available at PubMed

www.gacetamedicademexico.com

0016-3813/@ 2021 Academia Nacional de Medicina de México, A.C.. Published by Permanyer. This is an open access article under the CC BY-NC-ND license (http://creativecommons.org/licenses/by-nc-nd/4.0/). 
renal, neurological, cutaneous, endocrine, hematological and immune disorders ${ }^{1}$.

About one out of every two COVID-19 patients will develop anosmia. Consequently, loss or new changes in the sense of smell have become a highly suggestive symptom of the infection ${ }^{2}$, causing for patients to undergo diagnostic tests and isolate themselves from others. Up to $90 \%$ of patients will experience a significant recovery of the sense of smell within four weeks after their infection.

The pathogen responsible for COVID-19, severe acute respiratory syndrome coronavirus 2 (SARSCoV-2), uses spike proteins present on its surface to bind to angiotensin-converting enzyme 2 (ACE2) receptor. This receptor is expressed in several body tissues, including the olfactory bulbs, airway epithelium, lung parenchyma, vascular endothelium, kidney, small intestine and central nervous system (CNS) ${ }^{3}$.

Within the CNS, the ACE2 receptor is expressed on neurons, astrocytes and oligodendrocytes, and it is concentrated in the substantia nigra, ventricles, medial temporal gyrus and posterior cingulate cortex. There are several plausible mechanisms by means of which the virus can achieve neuroinvasion, including entry through the olfactory nerve, synaptic transfer along infected neurons, leukocyte migration across the bloodbrain barrier and vascular endothelium infection ${ }^{3}$.

Although the olfactory symptoms associated with COVID-19 have commonly been described as a sudden loss of smell or taste, there is a wide array of chemosensory dysfunction manifestations. These include altered orthonasal or retronasal smell, altered taste, parosmia, parageusia and phantosmia. In addition to the different types of alterations, there are also varying levels of severity, such as hyposmia, anosmia, hyperosmia, hypogeusia and ageusia ${ }^{4}$.

Although the majority of patients who experience olfactory dysfunction associated with SARS-CoV-2 infection can easily identify the symptom, the instruments for objectively measuring this condition (e.g., psychophysical assessment tools that evaluate at least one of the following: threshold, odor discrimination or identification) are often unavailable, as also are healthcare professionals trained to perform this type of tests. Furthermore, the potential the virus has for causing respiratory failure, added to the difficulty of having to work with personal protective equipment often limit how detailed physical examination or history taking of these patients can be, which can have an impact on how much information is collected with regard to olfactory alterations ${ }^{4}$.
After having treated more than three thousand patients with COVID-19, we noticed a distinctive manifestation of olfactory recovery. More than 20 patients attended follow-up appointments reporting that the last odors they regained the ability to perceive were those of their own bodies and, in particular, of their own stools. Several of these patients also reported that these odors even appeared pleasant to them.

These cases of olfactory dysfunction would be regarded as parosmias, i.e., altered perception of a smell. Other related terms to be considered include dysosmia/cacosmia (a usually unpleasant perception of a smell) and phantosmia (perception of a non-existent smell). Parosmias are believed to occur due to ephaptic firing in demyelinated neurons, i.e., electrical shunts not mediated by neurotransmitters. Paradoxically, the presence of these symptoms often suggests damage to structures of the olfactory tract, as well as the potential for these structures to heal. This process can take years, but in some cases the damage can be irreversible depending on the cause ${ }^{5}$.

Pleasant parosmias are considered rare, and whether they entail a different significance than the more commonly described (unpleasant) dysosmias is unknown. Another interesting factor to be considered is that patients report these parosmias when smelling their own stool. Beyond being considered a generic waste material resulting from the digestive process, feces have the potential to reflect various aspects of an individual's overall health. Patient genetics, diet, digestive process and microbiome can influence several aspects of homeostasis, including metabolism, digestive system health, neural effects and inflammation ${ }^{6}$. Considering recent interest in investigating the potential uses of fecal microbiota transplants, it is becoming increasingly clear that feces are not only a waste material, and that, in fact, they can have both a physiological and a pathological role in people's life. The reason for the specificity of our patients' symptoms (e.g., parosmias that occur with the smell of stools) is not clear, but could represent changes in the aforementioned elements that are relevant to fecal composition. These unusually pleasant parosmias could even represent an ability to detect such changes.

Olfactory alterations tend to become more common as people age, but can also be associated with certain pathologies such as traumatic brain injuries, exposure to certain medications or toxins (including chronic alcohol consumption and smoking), several 
neurodegenerative disorders (including Alzheimer's disease, Parkinson's disease, Lewy body dementia and frontotemporal dementia), multiple sclerosis, migraine, epilepsy, diabetes mellitus, hypothyroidism, chronic liver disease, chronic kidney disease and vitamin B12 or folate deficiency?.

It is not yet clear why some patients develop anosmia during SARS-CoV-2 infection and others do not. Furthermore, whether having experienced this symptom could be associated in the future with any of the aforementioned comorbidities is not known. The parosmias pleasant to own body odors described by our patients during their olfactory recovery stage do not appear to have been previously described, and the significance of said symptom also continues to be an enigma.

We consider of interest to report this apparently undescribed symptom in order to document its existence and keep it in mind along with other olfactory alterations as care and follow-up continue to be provided to SARS-CoV-2-infected patients. In addition, further characterization of these pleasant parosmias could contribute to the study and understanding of other olfactory disorders.

\section{Funding}

There was no funding for the preparation of the manuscript.

\section{Conflict of interests}

The authors declare that they have no conflicts of interest.

\section{Ethical disclosures}

Protection of human and animal subjects. The authors declare that no experiments were performed on humans or animals for this research.

Confidentiality of data. The authors declare that they have followed the protocols of their work center on the publication of patient data.

Right to privacy and informed consent. The authors declare that no patient data appear in this article.

\section{References}

1. Ramos-Casals M, Brito-Zerón P, Mariette X. Systemic and organ-specific immune-related manifestations of COVID-19. Nat Rev Rheumatol. 2021;17(6):315-32.

2. Walker A, Pottinger G, Scott A, Hopkins C. Anosmia and loss of smell in the era of covid-19. BMJ. 2020;370:m2808.

3. Zubair AS, McAlpine LS, Gardin T, Farhadian S, Kuruvilla DE, Spudich S. Neuropathogenesis and neurologic manifestations of the coronaviruses in the age of coronavirus disease 2019. JAMA Neurol. 2020;77(8):1018-27.

4. Whitcroft KL, Hummel T. Olfactory dysfunction in COVID-19 - Diagnosis and Management. JAMA. 2020;323(24):2512-4.

5. Hawkes C. Parosmia: treatment, mechanism, and types. BMJ. 2020;371:m4739.

6. Fan Y, Pedersen O. Gut microbiota in human metabolic health and disease. Nat Rev Microbiol. 2021;19(1):55-71.

7. DeVere R. Disorders of taste and smell. Continuum (Minneap Minn). 2017;23(2):421-26. 